MAREK M. TYTKO* - KRAKÓW

\title{
STUDIA TEOLOGICZNE FRANCISZKA KAROLA BLACHNICKIEGO W UNIWERSYTECIE JAGIELLOŃSKIM 1945-1950 ORAZ POCZĄTKI KONCEPCJI ŚWIĘTOŚCI W JEGO TEOLOGII MORALNEJ I PASTORALNEJ
}

W rozbudowanej literaturze przedmiotu dotyczącej osoby ks. Franciszka Karola Blachnickiego nie ma osobnego studium na ww. temat z zakresu historii koncepcji religijnej, stąd w niniejszym artykule podjęto próbę zasygnalizowania tematu, nie wyczerpując jednak poruszanej problematyki historyczno-teologicznej oraz pedagogicznej (skoro mowa o studiach wyższych, które przynależą do cyklu edukacji człowieka). Chodziło o skierowanie uwagi na niektóre wskazówki historyczno-teologiczne dotyczące ks. Blachnickiego w kontekście jego studiów uniwersyteckich, co zostało pokazane na przykładach. Niniejszy tekst nie pretenduje do miana całościowego zarysu monograficznego, ale tylko ukazuje wstępnie problem istotny nie tylko dla teologii moralnej (geneza koncepcji teologicznej) ale także dla pedagogiki religijnej, skoro autor jest twórcą koncepcji wychowania realizowanego do dziś w Ruchu Swiatło-Życie, swoistym „skautingu katolickim” (harcerstwie chrześcijańskim). Na teologii wiary, nadziei, miłości ${ }^{1}$ ks. Blachnicki budował ruch oazowy, który prezentuje własną odrębność nadaną mu przez założyciela. W istocie ks. Blachnicki zbudował swoją własną pedagogikę kultury chrześcijańskiej ${ }^{2} \mathrm{w}$ oparciu m.in. o teologię biblijną, zwłaszcza czerpiąc inspirację ze św. Pawła i św. Jana, katolicką teologię moralną i dogmatyczną, trynitologię, chrystologię, mariologię i wskazówki Vaticanum II, nadto w oparciu o własne, fenomenalne doświadczenie świata współczesnego. W niniejszym artykule

* Marek M. Tytko - dr pedagogiki, starszy bibliotekarz w Archiwum Uniwersytetu Jagiellońskiego.

${ }^{1}$ M. M. Tytko, Pedagogika kultury chrześcijańskiej. Wychowanie do wiary, nadziei i mitości w koncepcji ks. Franciszka Karola Blachnickiego, w: Wychowanie w rodzinie chrześcijańskiej. W 25 rocznice adhortacji apostolskiej Jana Pawła II «Familiarsis Consortio». Przestanie moralne Kościoła, red. ks. K. Jeżyna i ks. T. Zadykowicz, Lublin 2008, s. 193-220.

${ }^{2}$ M. M. Tytko, Kultura w koncepcji ks. Franciszka Karola Blachnickiego (wstep do problematyki), „Kultura i Edukacja” (Toruń), [w druku]. 
zastosowano zasadniczo historyczną metodę badawczą, akceptowaną w naukach pedagogicznych i teologicznych - analizę dokumentu3. Odrębnie, w innym artykule, opisano elementy animacji kultury chrześcijańskiej metodą skautingu w Ruchu Światło-Życie ks. Franciszka Karola Blachnickiego, która to animacja wyrasta z chrześcijańskiej, personalistycznej pedagogiki kultury, prezentowanej w istocie przez założyciela tzw. oaz .

Artykuł jest próbą zasygnalizowania zagadnienia, bez intencji jego wyczerpania, bez ukazywania pełnej, systematycznej monografii koncepcji teologicznomoralnych autorstwa ks. Blachnickiego. Jednak oeuvre autora zapisane na około ośmiuset pięćdziesięciu kasetach magnetofonowych z rejestracją wypowiedzi twórcy oazy (według stanu z 2002 roku) nie zostało przetransponowane w pełni z formy dźwiękowej na formę papierową. Nie zostały wydane wszystkie maszynopisy ks. Blachnickiego. Dopiero po całościowym, krytycznym opublikowaniu jego pełnego dorobku można się zając w pełni źródłowym opracowaniem poszczególnych wątków koncepcyjnych ks. Blachnickiego, tj. kwestii pedagogicznych czy teologicznych, w tym - motywów charakterystycznych dla teologii moralnej. Poza tym nie opracowano w całości, nie wyzyskano dla teologii, dla pedagogiki, dla historii koncepcji pedagogicznych i dla koncepcji teologicznych wszystkich dotychczas istniejących publikacji autorstwa ks. Blachnickiego (do 2002 roku około 1060 pozycji notowanych przez Bibliografie prac ks. Franciszka Blachnickiego). Stąd przyczynkowość nie roszcząca sobie pretensji całościowego ujęcia tematu. W niniejszym tekście istotne są przykłady, które pokazują jakim torem szło rozumowanie młodego Franciszka K. Blachnickiego studiującego wtedy w UJ, w duchu wychowania chrześcijańskiego, w duchu teologii świętości, a były to czasy stalinizmu, co trzeba uwzględnić jako właściwy kontekst historyczny. Artykuł z przyczyn obiektywnych pomija także późniejszą formację teologiczną ks. Blachnickiego w Katolickim Uniwersytecie Lubelskim (por. źródła archiwalne), co jest osobną kwestią do analizy (licencjat, doktorat i habilitacja w KUL, nie zatwierdzona przez komunistyczne władze państwowe PRL).

Należałoby przyjrzeć się także koncepcji człowieka w dorobku ks. Blachnickiego, następnie jego koncepcji wartości, koncepcji etycznej (tu jest miejsce dla badań z zakresu teologii moralnej), w końcu jego koncepcji pedagogicznej. Takie ujęcie gwarantuje właściwe odczytanie spuścizny po ks. Franciszku K. Blachnickim, wymaga jednak pełnych i systematycznych studiów, czego dotąd nie podjęto. $\mathrm{W}$ innym miejscu opisano koncepcję człowieka, wartości i wychowania w pismach tegoż Sługi Bożego 5 . Wiara, nadzieja i miłość są tylko ważnymi wartościami w hierarchii aksjologicznej ks. Blachnickiego, na której szczycie jest

${ }^{3}$ B. Łuczyńska, Badania historyczne $w$ pedagogice, w: Orientacje $w$ metodologii badań pedagogicznych, red. S. Palka, Kraków 1998, s. 121-134, bibliogr.

${ }^{4}$ Marek M. Tytko, Animacja kultury chrześcijańskiej metoda skautingu w Ruchu Światto - Życie ks. Franciszka Karola Blachnickiego, w: Wychowanie chrześcijańskie metoda harcerska, red. A. Petkowicz, [w druku].

${ }^{5}$ Marek M. Tytko, Człowiek, wartości, wychowanie - w koncepcji ks. Franciszka Karola Blachnickiego, [książka w przygotowaniu do druku]. 
świętość, a dobrem-celem ostatecznym jest Bóg i człowiek zjednoczony z Bogiem.

\section{Franciszek Karol Blachnicki (1921-1987), teolog-pedagog. Wczesne elementy formacji na studiach w Uniwersytecie Jagiellońskim} (1945-1950).

W niniejszym studium pominięto wczesne, przedwojenne etapy formacji rodzinnej, szkolnej, skautingowej, wojskowej Franciszka Karola Blachnickiego. Tu tylko zwraca się uwagę na znany badaczom proces nawrócenia (metanoię), który nastapił dnia 17 czerwca 1942 podczas oczekiwania Franciszka Blachnickiego na wykonanie wyroku śmierci, wydanego przez niemiecki Sąd III Rzeszy w Katowicach. W więzieniu katowickim dokonało się nawrócenie Blachnickiego na osobową wiarę w Jezusa Chrystusa. Tu podjął decyzję o oddaniu się na służbę Bogu. Okupacyjne elementy życiorysu założyciela oaz opisano w innym miej$\mathrm{scu}^{6}$.

Po II wojnie Franciszek Karol Blachnicki podjął studia na Wydziale Teologicznym Uniwersytetu Jagiellońskiego (1945-1950), wstapiwszy do Śląskiego Seminarium Duchownego, mieszczącego się podówczas w Krakowie w budynku przy al. Mickiewicza 3. Od roku akademickiego 1945/1946 do 1949/1950 studiował na pięcioletnich studiach w Wydziale Teologicznym Uniwersytetu Jagiellońskiego ${ }^{7}$. W Krakowie za sprawą studiów teologicznych dokonała się zasadnicza formacja duchowa Blachnickiego. Poniżej przytoczono dotąd zupełnie nieznane badaczom fakty z okresu jego krakowskich studiów na podstawie unikatowych, niepublikowanych dokumentów zachowanych w Archiwum UJ w jego teczce osobowej ${ }^{8}$. W czasie gdy Franciszek Karol Blachnicki studiował teologię, jego ojciec był urzędnikiem Ubezpieczalni Społecznej, mieszkał przy ul. św. Katarzyny 26 w Tarnowskich Górach. Kleryk Blachnicki deklarował polską przynależność państwową.

Ówczesny program uniwersyteckich studiów teologicznych (realizowanych w Wydziale Teologicznym Uniwersytetu Jagiellońskiego, zlikwidowanym w 1954

\footnotetext{
${ }^{6}$ Bibliografia prac ks. Franciszka Blachnickiego, oprac. G. Wilczyńska, Krościenko 2002, s. 7 i inn.

${ }^{7} \mathrm{Na}$ temat historii Wydziału Teologicznego UJ w czasie wojny por. M. Barcik, Wydziat Teologiczny Uniwersytetu Jagiellońskiego (1939-1945). Studia z dziejów Wydziału Teologicznego Uniwersytetu Jagiellońskiego, Tom XIII/1, Kraków 2001, s. 182. Druga część książki tegoż samego autora, dotycząca dziejów Wydziału Teologicznego UJ (19451954) znajduje się w przygotowaniu, dotyczy m. in. grona wykładowców, struktury i programu studiów teologicznych, poszczególnych studentów, w tym $\mathrm{m}$. in. postaci $\mathrm{F}$. Blachnickiego, dziejów poszczególnych katedr, zakładów oraz likwidacji tegoż Wydziału UJ przez władze komunistyczne 1953/1954.

${ }^{8}$ Teczka studencka Franciszka Blachnickiego por. sygn. AUJ WT II 252, teczki studenckie Wydziału Teologicznego UJ, Blachnicki Franciszek.
} 
r. $\left.{ }^{9}\right)$ przewidywał następujące przedmioty, zgodnie z zachowanymi dokumentami: 1) na pierwszym roku: filozofia ([kurs] I, II), historia Kościoła powszechnego ([kurs] I i II), wstęp do Pisma Świętego, archeologia biblijna, wstęp do teologii, język grecki, język hebrajski, język łaciński, 2) na drugim roku: filozofia ([kurs] I, II), teologia fundamentalna, historia Kościoła w Polsce, filozofia i teologia moralna, egzegeza Starego Testamentu, patrologia, język łaciński, 3) na trzecim roku: dogmatyka, historia dogmatów, teologia moralna, egzegeza Starego Testamentu, wstęp do Nowego Testamentu, prawo kanoniczne, historia sztuki kościelnej, język aramejski. W nieznanych badaczom a zachowanych w Archiwum UJ, protokołach ze studiów F. Blachnickiego, dane na temat wspomnianych. trzech pierwszych lat nie zostały zanotowane (pozostawiono puste rubryki). Wypełniono natomiast rubryki dotyczące czwartego i piątego roku studiów. Zapis w protokole dot. Franciszka K. Blachnickiego podaje: a) nazwę przedmiotu, b) datę (nie zawsze), c) ocenę $\mathrm{w}$ jezyku łacińskim (eminenter, valde bene), d) podpis egzaminatora (zwykle księdza profesora lub ks. doktora) ${ }^{10}$. Zapis (rozszerzony o imiona, czasem o pełne nazwiska i stopnie) brzmi zaś następująco. 4) Czwarty rok [1948/1949]: dogmatyka (eminenter, ks. prof. Ignacy Różycki), dogmatyka (II) [pusto], historia dogmatów [pusto], teologia moralna (eminenter, ks. prof. Władysław Wicher), egzegeza Nowego Testamentu (valde bene, ks. prof. Piotr Stach), prawo kanoniczne (valde bene, ks. prof. Jan Krzemieniecki), liturgika (eminenter, ks. dr Jan Wierusz Kowalski), pedagogika i katechetyka (eminenter, ks. dr Józef Rychlicki), język arabski (akadyjski) [pusto], etyka społeczna (eminenter, ks. dr Jan Piwowarczyk). 5) Rok piaty [1949/1950]: dogmatyka (II) (16 czerwca [1950 r.], eminenter, ks. Eugeniusz Florkowski), prawo kanoniczne (6 czerwca [1950], eminenter, ks. prof. Jan Krzemieniecki), [teologia] pastoralna (eminenter, ks. dr Herbert Bednorz), homiletyka (eminenter, ks. Julian Groblicki), katechetyka (17 czerwca [1950], eminenter, ks. dr Józef Rychlicki), etyka społeczna (20 czerwca [1950], eminenter, ks. dr Jan Piwowarczyk), Nowy Testament [pusto], medycyna pasterska (eminenter, dr med. Marian Kusiak). Rubryka dotycząca roku szóstego (katechetyka, homiletyka, ascetyka i mistyka, etyka społeczna, medycyna pasterska, Nowy Testament) nie została wypełniona, ponieważ nie wprowadzono szóstego roku teologii po II wojnie na studiach teologicznych, mimo istnienia przedwojennych programów, planów wdrożenia studiów sześcioletnich, których nie zrealizowano wtedy pod naciskiem władz komunistycznych. Jednakże w Wydziale Teologicznym UJ posługiwano się po II wojnie światowej gotowymi, wydrukowanymi przed wojną formularzami dotyczącymi toku studiów, stąd różnica i brak wypełnienia rubryk roku szóstego.

${ }^{9}$ L. Hajdukiewicz, M. Barcik, Wydziat Teologiczny 1850-1954, w: Inwentarz akt wydziałów i studiów Uniwersytetu Jagiellońskiego 1850-1939 (1954), red. J. Michalewicz, Kraków 1997, s. 25-67, seria: Z prac Archiwum Uniwersytetu Jagiellońskiego, red. J. Michalewicz, seria A: Inwentarz Archiwum Uniwersytetu Jagiellońskiego, tom 7.

${ }^{10}$ Identyfikacji niewyraźnie zapisanych podpisów (stopni, imion i nazwisk) dokonał w większości przypadków, na prośbę niżej podpisanego, kustosz Archiwum UJ, mgr Mieczysław Barcik (XI 2007). Podpis Herberta Bednorza zidentyfikowany został przez ww. kustosza, na podstawie teczki osobowej sygn. AUJ S III 246, Bednorz Herbert. 
Przedstawiony powyżej, po raz pierwszy tak szczegółowo, tok studiów teologicznych kleryka F. Blachnickiego oraz nazwiska jego nauczycieli, wykładowców, mistrzów, zachowane $\mathrm{w}$ dokumentach w Archiwum Uniwersytetu Jagiellońskiego, pozwalają na wyrobienie sobie opinii o formacji duchowej, o rodzaju zdobywanej wiedzy oraz brakach w wiedzy (puste miejsca z powodu zmienionego programu wykładów w stosunku do pierwotnie założonego, przedwojennego planu studiów teologicznych). Reforma tych studiów weszła praktycznie w UJ w 1938 roku, zaczęto ją realizować przez pierwszy rok akademicki 1938/1939, lecz nie doszła do skutku w całości. Taki profil formacji duchowej młody F. Blachnicki zawdzięczał studiom teologicznym w UJ po II wojnie światowej, a przede wszystkim ówczesnym wykładowcom krakowskim. Warto zauważyć nazwisko mistrza z zakresu teologii moralnej - ks. prof. Władysława Wichra oraz ocenę celująca, jaką otrzymał młody kleryk u tego wykładowcy. Odrębną kwestią jest przeprowadzenie komparatystycznych badań porównujących myśl ks. Blachnickiego oraz myśl ww. wykładowców z Wydziału Teologicznego UJ. Zwłaszcza porównanie dorobku pisanego ks. prof. W. Wichra oraz dorobku ks. Blachnickiego mogłoby doprowadzić do konkluzji w kwestii wpływu, inspiracji. Tu otwiera się pole badawcze dla historyka teologii moralnej, dotąd niewykorzystane.

Co do innych przedmiotów w Wydziale Teologicznym UJ, to należałoby pominąc zajęcia prowadzone przez dra med. Mariana Kusiaka, wykładowcę medycyny pasterskiej, bo w tej dziedzinie Blachnicki nie wypowiadał się w piśmiennictwie. W obszarze badawczym pozostaje dorobek naukowy autorów takich, jak: 1) ks. dr Herbert Bednorz (teologia pastoralna), 2) ks. Eugeniusz Florkowski (dogmatyka), 3) ks. Julian Groblicki (homiletyka), 4) ks. prof. Jan Krzemieniecki (prawo kanoniczne), 5) ks. dr Jan Piwowarczyk (etyka społeczna), 6) ks. prof. Ignacy Różycki (dogmatyka), 7) ks. dr Józef Rychlicki (pedagogika i katechetyka), 8) ks. prof. Piotr Stach (egzegeza Nowego Testamentu), 9) ks. prof. Władysław Wicher (teologia moralna), 10) ks. dr Jan Wierusz Kowalski (liturgika). Spośród przedmiotów dotyczących wartości istotne były: teologia moralna, etyka społeczna a także pedagogika. $Z$ aksjologiczno-pedagogicznego i historiograficzno-teologicznego punktu widzenia, dla wyjaśnienia genezy koncepcji wychowawczej oraz teologicznej założyciela oaz istotne byłyby więc nazwiska mistrzów Blachnickiego, takich, jak: 1) ks. dr Jan Piwowarczyk (etyka społeczna), 2) ks. dr Józef Rychlicki (pedagogika), 3) ks. prof. Władysław Wicher (teologia moralna). Wskazuje się niniejszym na konieczność przeprowadzenia systematycznych badań porównawczych przez pedagogikę komparatystyczną w zakresie wychowania chrześcijańskiego nad koncepcjami: 1) ks. J. Piwowarczyka i ks. F. K. Blachnickiego, 2) ks. J. Rychlickiego i ks. F. K. Blachnickiego, 3) ks. W. Wichra i ks. F. K. Blachnickiego. Czy istotnie myśl krakowskich mistrzów uniwersyteckich wpłynęła, w jakim stopniu i obszarze na koncepcję wychowawczo-moralną założyciela oaz? Jest to odrębne zagadnienie warte podjęcia w kilku osobnych studiach monograficznych (dogłębnych i obszernych, udokumentowanych źródłowo). Tu tylko sygnalizuje się problem teologiczno-historyczny do pełnego zbadania metodami historiograficznymi $\mathrm{m}$. in. za pomocą analizy dokumentów, pub- 
likacji oraz ineditów. Warto zwłaszcza zbadać wpływ poglądów pedagogicznych ks. dra Józefa Rychlickiego na pedagogiczne koncepcje młodego adepta teologii, wszak młody kleryk czerpał wzory koncepcyjne także na wykładach z zakresu pedagogiki i katechetyki, a nawet wykazywał się celującą znajomością w zakresie wiedzy z tych przedmiotów, co potwierdził egzamin. Czy ks. dr Józef Rychlicki był tu tylko formalnym ,przekazicielem” wiedzy dydaktycznej, wiadomości pedagogiczno-katechetycznych czy także mistrzem, wzorem dydaktyka do naśladowania? Należałoby ten obszar zbadać w świetle zachowanych dokumentów.

Poniżej po raz pierwszy przedstawiono nieznane zupełnie badaczom wypisy $\mathrm{z}$ dokumentów dotyczących wykształcenia ks. Blachnickiego. Dyplom magistra teologii (L. 468/50) wydany został przez Uniwersytet Jagielloński w Krakowie Wydział Teologiczny na nazwisko Franciszek Karol Blachnicki, ur. 24 marca 1921 r. w Rybniku. W dyplomie magisterskim stwierdzono, że wyżej wymieniony „odbył przepisane studia filozoficzno-teologiczne na Wydziale Teologicznym Uniwersytetu Jagiellońskiego w Krakowie od roku 1945/46 do roku 1949/50 i zdał następujące egzaminy: $\mathrm{z}$ filozofii chrześcijańskiej i historii filozofii z wynikiem celującym, z nauk biblijnych Nowego Zakonu z wynikiem bardzo dobrym, z nauk biblijnych Starego Zakonu z wynikiem celującym, z historii Kościoła katolickiego $\mathrm{z}$ wynikiem celującym, $\mathrm{z}$ teologii fundamentalnej (apologetyki) $\mathrm{z}$ wynikiem celującym, z teologii dogmatycznej z wynikiem celującym, z teologii moralnej ogólnej i szczegółowej z wynikiem celującym, z prawa kanonicznego z wynikiem celującym, $z$ teologii pastoralnej z liturgiką i homiletyką z wynikiem celującym, z pedagogiki, katechetyki i metodyki z wynikiem celującym, oraz przedstawił z wynikiem bardzo dobrym pracę magisterską na temat: »Istota świętości. Studium religijno-filozoficzne«. Wobec tego Rada Wydziału Teologicznego Uniwersytetu Jagiellońskiego na wniosek Komisji Egzaminacyjnej nadaje księdzu Franciszkowi Karolowi (2 im.) BLACHNICKIEMU stopień MAGISTRA TEOLOGII. Jako dowód zakończenia studiów uniwersyteckich // w Krakowie, dnia 20 października 1950 r." ${ }^{\prime 11}$ (pieczęcie i podpisy rektora i dziekana - nieczytelne).

Tak przedstawiał się proces kształcenia młodego kleryka F. Blachnickiego. Student ten wyróżniał się w nauce, o czym świadczą oceny celujące i bardzo dobre, uzyskiwane na egzaminach. Zdobyta wiedza uks. Franciszka K. Blachnickiego, w świetle dokumentów, była oceniana wysoko przez jego wykładowców. Ks. Blachnicki niewatpliwie był studentem zdolnym, utalentowanym oraz inteligentnym. Umiał zdobywać wiedzę i ją przyswajać oraz przekazywać ją podczas egzaminów, co także jest dużą umiejętnością.

\section{Praca magisterska ks. Franciszka Karola Blachnickiego (1950) dotycząca istoty świętości}

W koncepcji teologii moralnej, sformułowanej przez młodego Blachnickiego głównym celem chrześcijanina jest świętość. Wychowanie chrześcijańskie dąży

${ }^{11}$ AUJ WT II 252. Tamże. Teczka studencka Franciszka Blachnickiego. 
do wychowania człowieka do świętości, mimo wad ludzkich. O zainteresowaniu Blachnickiego problematyką świętości już wtedy (w 1950 r.) świadczy samo podjęcie takiego, a nie innego tematu pracy magisterskiej. Zachowała się dotąd niepublikowana Ocena pracy ks. Franciszka Blachnickiego pt. „Istota świętości. Studjum religijno-filozoficzne na tle powieści Wt. Grabskiego »W cieniu kollegiaty «[”]. Autorem tej Oceny jest ks. prof. Marian Michalski, promotor. Ten mistrz teologii zapisał dnia 25 czerwca 1950 roku w owej Ocenie następujące zdania o swoim uczniu, już wyświęconym ks. Franciszku Karolu Blachnickim i jego pracy naukowej na stopień magistra teologii. Tekst ten dotąd był niepublikowany, zachowano oryginalną, ówczesną pisownię, dodano tylko kursywę i dopowiedzenia od autora niniejszego artykułu w nawisach kwadratowych: „Autor wziął za temat pracy wycinek z problematyki nowoczesnej filozofii religii, dotyczący zagadnienia istoty świętości człowieka, przy rozumieniu słowa »świętość« w znaczeniu religijnym. Okazję do podjęcia tego tematu dały autorowi recenzje powieści Wł. Grabskiego p.t. »W cieniu kollegiaty«, w której pisarz starał się zagadnienie świętości po swojemu rozwiązać. Recenzje książki wyraziły zgoła rozbieżne opinie o trafności rozwiązania zagadnienia przez Grabskiego. Autor pracy uważa, że rozbieżności te pochodzą $z$ fałszywego ujęcia przez recenzentów zasadniczych myśli pisarza, przez położenie nacisku na rzeczy w powieści nieistotne, pominięcie natomiast momentów istotnych. Sam stara się błąd ten naprawić, przy czym dochodzi do wniosku, że zasadniczy pogląd Grabskiego na istotę świętości jest zupełnie trafny i odpowiada w pełni poglądom w tej materii zarówno nowoczesnej naukowej filozofii religii, jak ascetyki i teologii biblijnej. // Obrany temat rozwija autor na szerokim tle religijno-filozoficznym i egzegetyczno-biblijnym, w czterech zasadniczych rozdziałach: I. Istota świętości wedtug nowoczesnej filozofii religii, - II. Istota świętości wedtug Ewangelii, - III. Problem świętości w ujęciu Grabskiego w powieści »W cieniu kollegiaty «, — IV. Ujęcie (powinno być raczej: rozwiqzanie) problemu świętości przez Grabskiego, w świetle filozofii religii. // Oceniając pracę[,] należy podkreślić przedewszystkiem [sic!] staranne, gruntowne i solidne przepracowanie problemu, zarówno w zakresie partji [sic!] ogólnych, poświęconych tłu religijno-filozoficznemu, jak w zakresie partji [sic!] szczegółowych, dotyczących analizy treści powieści Grabskiego. Analiza treści odznacza się wnikliwością i głębokością ujęcia myśli pisarza, ujęcia zaś systematycznie zanalizowanych ustępów są śmiałe i ścisłe. Rozkład materiału naogół [sic!] szczęśliwy. Sposób wyrażania się prosty, jasny, naukowy. - Z niedociągnięć możnaby wymienić zacieśnienie tła religijno-filozoficznego niemal wyłącznie do szkoły fenomenologicznej. Ponadto nie wydaje się potrzebny ani korzystny dla całości konstrukcji pracy rozdział ostatni (V.: Problem "pokutnika z pogańska twarzq" w perspektywie wspótczesnej rzeczywistości i dziejów Kościoła). Wreszcie niektóre ustępy pracy można by ująć nieco zwięźlej i treściwiej, by nie nużyć czytelnika rozwlekaniem tego, co samo przez się jest łatwe do zrozumienia. // W rezultacie praca spełnia wszystkie warunki wymagane do rozprawy magisterskiej, a nawet wychodzi ponad poziom przeciętnego elaboratu, wykazując wybitne uzdolnienie, szeroką wiedzę i sumienność pracy autora. Oceniam ją jako bardzo dobrą i pro- 
ponuję zwolnienie autora od egzaminu ustnego. // X. Marian Michalski // Kraków 25 VII 1950""12.

Warto w odrębnym studium poddać badaniom historiograficzno-pedagogicznym lub historiograficzno-teologicznym wpływ ks. Mariana Michalskiego na ucznia, ks. Franciszka Karola Blachnickiego, zwłaszcza w zakresie wychowania do świętości czy wychowania moralnego (wychowania do wartości i wychowania przez wartości). Odrębną kwestią jest wpływ lektur (np. W. Grabskiego, fenomenologów: M. Schelera, R. Ingardena, P. Tillicha i in. czy filozofów religii) na koncepcje filozoficzno-pedagogiczne i teologiczno-filozoficzne ks. F. K. Blachnickiego. To także należałoby zbadać w osobnych studiach komparatystycznych.

Widać jednak, na przykładzie zacytowanej recenzji z epoki, rozwój teologiczny, filozoficzny, charakterystyczne cechy umysłowości i duchowości młodego Blachnickiego: szerokość ujęcia, przenikliwość, szukanie istoty rzeczy, przy jednoczesnym wieloaspektowym analizowaniu i drobiazgowym opisywaniu zagadnień, zainteresowanie literatura piękna, wychwytywanie elementów teologicznych w literaturze pięknej, predylekcja do wychowania przez literaturę, pragnienie ewangelizacji pogan, tj. także ateistów, rzetelność, uczciwość i solidność w zdobywaniu wiedzy, o czym świadczą oceny celujące i bardzo dobre na egzaminach, które to cechy doprowadziły go do stworzenia koncepcji formacji człowieka przez wartości (dobra-środki) ku dobrom-celom.

\section{Podsumowanie}

Koncepcja teologiczno-moralna i wychowawcza młodego ks. Blachnickiego przejawiała się początkowo w obszarze wychowania człowieka do świętości, wychowania dzięki literaturze, ale nade wszystko poprzez osobiste przeżycie i świadectwo. Metody osiągnięcia świętości indywidualnej we wspólnocie poprzez cnoty teologalne (wiarę, nadzieję, miłość) oraz przy udziale pedagogicznych metod pomocniczych to osobna kwestia, którą w całym swoim dorobku rozwijał tenże teolog. Fenomenologia świętości, poznana i ujęta filozoficznie przez Blachnickiego w toku krakowskich studiów teologicznych w UJ to zagadnienie teologii moralnej warte osobnego zbadania przez historyka myśli teologicznej lub historyka myśli

${ }^{12}$ Tamże. W oryginalnym tekście recenzji promotora jest usterka techniczna (błąd powtórzenia), ponieważ napisane jest dwukrotnie: „istoty istoty” zamiast: „istoty”. W cytacie powyższym usterkę tę pominięto (zapisano słowo: „,istoty” tylko jeden raz, tak jak być powinno). Inne słowa w powyższym cytacie zachowano w pisowni oryginalnej, właściwej dla polszczyzny przedwojennej. Uwaga: oryginał pracy magisterskiej ks. Blachnickiego został wypożyczony z UJ za rewersem przez ks. prof. Mariana Michalskiego i niezwrócony. Rewers ten zachował się w Archiwum UJ w teczce studenckiej Franciszka Karola Blachnickiego, ale praca magisterska - nie. Dalsze losy ww. egzemplarza pracy magisterskiej nie są znane autorowi niniejszego artykułu. Publikacja autorstwa Blachnickiego pt. Świętość w świetle filozofii religii, Lublin 1997, jest najprawdopodobniej przeredagowanym i skróconym tekstem jego pracy magisterskiej pt. Istota świętości. Studjum religijnofilozoficzne na tle powieści Wt. Grabskiego »W cieniu kollegiaty«, Kraków 1950. 
etycznej. Chodzi o typ teorii teologiczno-pedagogicznej, uskuteczniany później w praktyce w ruchu oazowym w Kościele rzymskokatolickim. Należałoby uchwycić w zarysie koncepcję teologii moralnej ks. Blachnickiego wraz ze wszystkimi reperkusjami dla jego koncepcji wychowawczej dla wychowania religijnego, wychowania w Ruchu Światło-Życie.

\section{BIBLIOGRAFIA}

\section{Źródla \\ Archiwum Uniwersytetu Jagiellońskiego w Krakowie}

AUJ, Wydział Teologiczny, teczki studenckie, sygn. WT II 252, Blachnicki Franciszek, [1945]-1950.

Blachnicki Franciszek, Istota świętości. Studium religijno-filozoficzne na tle powieści Władysława Grabskiego pt. ,,W cieniu kolegiaty”, Kraków 1950 [praca magisterska w Wydziale Teologicznym UJ, wypożyczona w 1951 r., obecne miejsce przechowywania ww. egzemplarza oryginału pracy nieznane].

Archiwum Katolickiego Uniwersytetu Lubelskiego Jana Pawła II w Lublinie

Blachnicki Franciszek, ks., Metoda przė̇yciowo-wychowawcza dziecięcych rekolekcji zamkniętych. Studium pedagogiczno-pastoralne, praca licencjacka, Lublin 1963, s. XIII, 397, sygn. AU KUL: T. lic. 219. [Promotor pracy: prof. dr Stefan Kunowski, recenzent: ks. prof. dr hab. Józef Pastuszka; tytuł licencjata został uzyskany w dniu 29 maja 1963 r.].

Blachnicki Franciszek, ks. Pośrednictwo Zbawcze Kościoła w ujęciu Franciszka Ksawerego Arnolda. Problem zasady formalnej teologii pastoralnej, praca doktorska, Lublin 1965, s. 353, sygn. AU KUL: T. d. 146. [Promotor: ks. prof. dr hab. Wincenty Granat, recenzenci: ks. prof. dr hab. Władysław Poplatek, KUL, ks. prof. dr hab. Józef Dejczak, ATK, stopień doktora uzyskany w dniu 19 czerwca 1965 r.].

Blachnicki Franciszek, ks., Eklezjologiczna dedukcja teologii pastoralnej, [praca habilitacyjna], wyd. Mała Poligrafia KUL, Lublin 1971, s. V, 529, sygn. AU KUL: T. h. 20. [Recenzenci: ks. prof. dr hab. Adam Szafrański, KUL, ks. prof. dr hab. Czesław Bartnik, ks. prof. dr hab. Henryk Bogucki, ATK; kolokwium habilitacyjne: 13 kwietnia 1973; zatwierdzenie przez Radę Wydziału Teologicznego KUL: 13 kwietnia 1973 r.; zatwierdzenie przez Senat Akademicki KUL 23 czerwca 1973 r.]. 


\section{Opracowania}

Barcik M., Wydziat Teologiczny Uniwersytetu Jagiellońskiego (1939-1945), Kraków 2001, s. 182.

Biela B., Bibliografia publikacji ks. Franciszka Blachnickiego, „Śląskie Studia Historyczno-Teologiczne", 25/26 (1992/1993) s. 223 - 231.

Biela B., Kościót - wspólnota: wspólnota jako zasada urzeczywistniania sie Kościoła w ujęciu ks. Franciszka Blachnickiego (1921-1987), Katowice 1993.

Biela B., Ks. Franciszek Blachnickim - uwarunkowania jego pogladów teologiczno-pastoralnych, „Śląskie Studia Historyczno-Teologiczne”, 25/26 (1992/1993) s. 205-221.

Biela B., Zarys koncepcji teologii pastoralnej ks. Franciszka Blachnickiego, Katowice 2004,

Blachnicki Franciszek, Świętość w świetle filozofii religii, Lublin 1997.

Hajdukiewicz L., Barcik M., Wydziat Teologiczny 1850-1954, w: Inwentarz akt wydziałów i studiów Uniwersytetu Jagiellońskiego 1850-1939 (1954), red. J. Michalewicz, Kraków 1997, s. 25-67, seria: „Z prac Archiwum Uniwersytetu Jagiellońskiego", red. Jerzy Michalewicz, seria A: Inwentarz Archiwum Uniwersytetu Jagiellońskiego, tom 7.

Kopeć J. J., Rutkowski A., Stuga Boży ksiqdz Franciszek Blachnicki (1921-1987) charyzmatyk Kościoła posoborowego: sesja naukowa w KUL (7.V.1998), „Liturgia Sacra”, 1 (1998), s. 127-130.

Kopeć J. J., Stuga Boży ks. Franciszek Blachnicki (1921-1987). Charyzmatyk Kościoła posoborowego, „Roczniki Teologiczne”, 8 (1998), s. 5-6.

Kowalski M. T., Wychowanie elit chrześcijańskich w ujęciu ks. Franciszka Blachnickiego, „Paedagogia Christiana”, 2 (2002) s. 177-188.

Łaszczyk M., Ruch „Światto - Życie” w stużbie odnowy parafii i duszpasterstwa wedtug koncepcji pastoralnej ks. Franciszka Blachnickiego, „Studia Włocławskie", 5 (2002) s. 198-215.

Łuczyńska B, Badania historyczne w pedagogice, w: Orientacje w metodologii badań pedagogicznych, red. Stanisław Palka, Kraków 1998, s. 121-134.

Marczewski M., Charyzmatyk Kościoła posoborowego [ks. Franciszek Blachnicki], „Ethos”, 13 (2000) nr 3, s. 331-334.

Marczewski M., Młodzież w Kościele w wizji ks. Franciszka Blachnickiego, „Ateneum Kapłańskie”, 128 (1997) z. 2, s. 180-188.

Marczewski M., Nauczyciel przeniknięty duchem i moca liturgii (ks. Franciszek Blachnicki 1921-1987), „Liturgia Sacra”, 9 (2003) nr 2, s. 331-347.

Marczewski M., Pedagogika katolicka jako pedagogika wiary w ujęciu ks. Franciszka Blachnickiego, „Paedagogia Christiana”, 2 (1998), s. 56-77.

Marczewski M., Posługa zbawcza Kościoła w ujęciu ks. Franciszka Blachnickiego, Lublin 2000.

Marczewski M., Posoborowy apostot formacji laikatu (Stuga Boży ks. Franciszek Blachnicki 24 III 1921 - 27 II 1987), „Roczniki Teologiczne”, 45 (1998) z. 8, s. 53-73. 
Marczewski M., Prawda - krzyż - wyzwolenie: polska teologia wyzwolenia epoki totalitaryzmu i jej aktualne przestanie, „Ethos”, 13 (2000) nr 3, s. 126-140.

Marczewski M., Rekolekcje więzienne: notatki z „rekolekcji zamkniętych” $w$ Centralnym Więzieniu $w$ Katowicach $w$ czasie od 15 marca do 19 lipca 1961 r., ks. Franciszka Blachnickiego, Krościenko 2001.

Marczewski M., Teologia Chrystusa-Stugi jako odpowiedź na znaki czasu, „Kieleckie Studia Teologiczne”, 1 (2002) cz. 2, s. 119-134.

Maślanka J., Ideał nowego człowieka w duchowości chrystologicznej ks. Franciszka Blachnickiego, „Ateneum Kapłańskie”, 140 (2003) z. 1, s. 98 - 108, streszczenie w jęz. włoskim (sommario).

Mikulski J., Polska teologia wyzwolenia: teologia wyzwolenia człowieka w ujęciu ks. Franciszka Blachnickiego, Tarnów 2002.

Narecki Z., Formacja duchowa chrześcijan świeckich w ujęciu Stugi Bożego ks. Franciszka Blachnickiego, „Roczniki Teologiczne”, 45 (1998) z. 8, s. 31-51.

Rutkowski A., Diakonia stużba Bogu i ludziom w nauczaniu księdza Franciszka Blachnickiego (Lublin, 9 maja 2001 r.), „Liturgia Sacra”, 7 (2001) nr 1, s. 140-144 .

Tytko M. M., Animacja kultury chrześcijańskiej metoda skautingu w Ruchu Światto - Życie ks. Franciszka Karola Blachnickiego ${ }^{13}$, w: Wychowanie chrześcijańskie metoda harcerska, red. Anna Petkowicz, Lublin, [w druku].

Tytko M. M., Człowiek, wartości, wychowanie - w koncepcji ks. Franciszka Karola Blachnickiego, [w druku].

Tytko M. M., Kultura w koncepcji ks. Franciszka Karola Blachnickiego (wstęp do problematyki), „Kultura i Edukacja” [w druku].

Tytko M. M., Pedagogika kultury chrześcijańskiej (wychowanie do wiary, nadziei i miłości) w koncepcji ks. Franciszka Karola Blachnickiego, w: Wychowanie w rodzinie chrześcijańskiej. W 25 rocznicę adhortacji apostolskiej Jana Pawła II Familiarsis Consortio. Przestanie moralne Kościoła, red. ks. Krzysztof Jeżyna i ks. Tadeusz Zadykowicz, Lublin 2008, s. 193-220.

Werbiński I., Droga do dojrzałości chrześcijańskiej wedtug ks.Franciszka Blachnickiego, „Studia Włocławskie”, 3 (2000) s. 296-311.

Wilczyńska G., Bibliografia prac ks. Franciszka Blachnickiego, Krościenko nad Dunajcem 2002, s. 94, 2 nlb.

${ }^{13}$ Referat na Międzynarodowe Sympozjum pt. Wychowanie chrześcijańskie metoda harcer$s k a$, Katolicki Uniwersytet Lubelski Jana Pawła II, Lublin 4 grudnia 2007 r. Grupa tematyczna pt. Wychowanie do świadectwa. Tekst złożony do druku w materiałach pokonferencyjnych KUL, Lublin 2008. 


\title{
FRANCISZEK KAROL BLACHNICKI'S THEOLOGICAL STUDIES AT THE JAGIELLONIAN UNIVERSITY 1945-1950 AND THE BEGINNING OF CONCEPTION OF SAINTHOOD (HOLINESS) IN HIS MORAL- AND PASTORAL THEOLOGY
}

\begin{abstract}
Summary
The article concerns rev. Franciszek Karol Blachnicki (born 1920, died 1987). The paper shows early period of his life, it focus on theological studies, which took place at the Jagiellonian University in years 1945-1950. The author presents unknown (inedited) documents preserved in the Archives of the Jagiellonian University, archival records concerning his education according to the program of the theological studying in the Faculty of Theology and evaluation of his master's work written by Blachnicki in 1950 year, concerning the essence of sainthood (holiness). The author of the article makes a hypothesis on theme relations between theological, ethical, pedagogical conceptions of Blachnicki's masters and his own theological, ethical, pedagogical conceptions.
\end{abstract}

